The Stability of the International Monetary

System 


\begin{abstract}
Also by W. M. Scammell
International Monetary Policy (2nd edition)

The London Discount Market

International Trade and Payments

International Monetary Policy: Bretton Woods and After

The International Economy Since 1945 (2nd edition)
\end{abstract}




\title{
The Stability of the International Monetary System
}

\author{
W. M. Scammell
}

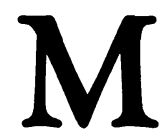

MACMILLAN

EDUCATION 
(C) W. M. Scammell 1987

All rights reserved. No reproduction, copy or transmission of this publication may be made without written permission.

No paragraph of this publication may be reproduced, copied or transmitted save with written permission or in accordance with the provisions of the Copyright Act 1956 (as amended).

Any person who does any unauthorised act in relation to this publication may be liable to criminal prosecution and civil claims for damages.

First published 1987

Published by

MACMILLAN EDUCATION LTD

Houndmills, Basingstoke, Hampshire RG21 2XS

and London

Companies and representatives

throughout the world

British Library Cataloguing in Publication Data

Scammell, W. M.

The stability of the international monetary system.

1. International finance

I. Title

332.4'5 HG3881

ISBN 978-0-333-38578-4

ISBN 978-1-349-18685-3 (eBook)

DOI 10.1007/978-1-349-18685-3

To $\mathrm{K}$ 


\section{Contents}

List of Tables vii

Preface viii

1 Introduction 1

2 The Necessities of the System 9

(i) Introduction $\quad 9$

(ii) International money 10

(iii) The institutional framework of international finance $\quad 13$

(iv) An adjustment mechanism 17

(v) Control of the international monetary system 21

(vi) Economics and the political realities 23

3 A Little History 26

(i) Introduction 26

(ii) The gold standard $\quad 27$

(iii) Flexible exchange rates 36

(iv) The Bretton Woods system 46

4 International Money 51

(i) Introduction $\quad 51$

(ii) What is international money? 52

(iii) Demand and supply 57

(iv) Are SDRs the answer? 64

5 What Sort of Exchange Rates? 72

(i) Introduction $\quad 72$

(ii) The adjustable-peg system and its critics 73

(iii) Free rates - or nearly so $\quad 80$

6 Theoretical Approaches to Adjustment 90

(i) Introduction $\quad 90$

(ii) Monetarism $\quad 92$

(iii) Monetarism and policy $\quad 99$

(iv) Monetarism and international policy 102 


\section{vi Contents}

7 The Role and Mechanism of Capital Flows 104

(i) Introduction 104

(ii) Capital flows in theory 105

(iii) The Euro-currency market 112

(iv) International private-sector lending 122

(v) Conclusion 126

8 Control of the International Monetary System 129

(i) Introduction 129

(ii) Centralisation versus groups 131

(iii) Economic relations of groups 139

(iv) Conclusion 145

9 Conclusion 147

(i) Strengths and weaknesses $\quad 147$

(ii) International money 148

(iii) Adjustment 150

(iv) Exchange rates 153

(v) Final conclusion 154

$\begin{array}{ll}\text { Index } & 157\end{array}$ 


\section{List of Tables}

4.1 Composition of Official Holdings of Reserve Assets, All Countries

5.1 Exchange Rate Arrangements for IMF

Currencies at 31 March 1986

7.1 External Assets and Liabilities of Banks in Some Reporting Countries, 1976

7.2 Non-Oil Developing Countries' External Debt

7.3 Developing Countries: Debt-Service Payments and Amortization Costs 


\section{Preface}

This book reflects an attempt to answer questions put to me by academic colleagues (who were not economists) at a time when the international financial system was exhibiting symptoms of strain and disintegration. Is it possible that the international monetary system could collapse? Through what processes could disintegration take place? My answer was given in an afternoon seminar with non-economist social scientists and a few curious economist colleagues, quick to pounce on errors of fact or reasoning.

The discussion which took place convinced me of two things which led me to persevere and rescue some of that discussion for a wider audience. First, the nexus of relationships which we call the international monetary system can be, and indeed is, best presented in a set of verbal propositions intelligible to most thinking people and free from the mathematical encumbrances with which, nowadays, economists try to glamorise their matter. Second, there is, in any event, an obligation to expound the problem in this way if one wishes to reach the audience one should reach, namely politicians, bankers, journalists, teachers and academics with time enough to stop being specialists.

I have presented the argument in book form much as I did in seminar, untidily and with some, perhaps pardonable, exaggeration. If it continues to evoke discussion it will have served its purpose.

Hamilton, Ontario

W. M.S.

June 1986 